Abstracta Iranica Abstracta Iranica

Revue bibliographique pour le domaine irano-aryen

Volume 22 | 2001

Comptes rendus des publications de 1999

\title{
Turkmen-English Dictionary. Kensington (MD), Dunwoody Press, 1999, x11-710 p.
}

\section{Stéphane A. Dudoignon}

\section{Q OpenEdition}

1 Journals

Édition électronique

URL : http://journals.openedition.org/abstractairanica/36201

DOI : 10.4000/abstractairanica.36201

ISSN : 1961-960X

\section{Éditeur :}

CNRS (UMR 7528 Mondes iraniens et indiens), Éditions de l'IFRI

\section{Édition imprimée}

Date de publication : 15 mai 2001

ISSN : 0240-8910

\section{Référence électronique}

Stéphane A. Dudoignon, « Turkmen-English Dictionary. Kensington (MD), Dunwoody Press, 1999, xII-710 p. », Abstracta Iranica [En ligne], Volume 22 | 2001, document 64, mis en ligne le 15 février 2010, consulté le 13 octobre 2020. URL : http://journals.openedition.org/abstractairanica/36201 ; DOI : https://doi.org/10.4000/abstractairanica.36201

Ce document a été généré automatiquement le 13 octobre 2020.

Tous droits réservés 


\title{
Turkmen-English Dictionary. Kensington (MD), Dunwoody Press, 1999, x11-710 p.
}

\author{
Stéphane A. Dudoignon
}

1 Très agréablement présenté, sous une forme élégante dans laquelle l'éditeur a mis beaucoup de soin, ce dictionnaire très clair et d'un usage particulièrement aisé présente, pour chaque terme turkmène noté en graphie cyrillique, ses principales traductions anglaises, suivies chacune d'un exemple emprunté à un texte turkmène, lui aussi traduit en anglais. Compte tenu de la fluctuation des politiques adoptées successivement au Turkménistan pour l'écriture de la langue nationale, au cours du $20^{\mathrm{e}}$ s. et jusqu'à une date fort récente, il faut peut-être regretter l'absence de tables de concordance entre les graphies arabe, latine des années 1930, cyrillique, et latine des années 1990. Mais le reproche principal que l'on peut faire à cet ouvrage est qu'il porte sur le patrimoine lexical turkmène de l'ex-URSS, sans s'ouvrir au turkmène d'Iran ou d'Afghanistan 医 bien que ces derniers relèvent pour l'essentiel de la culture orale. Nous devons cependant nous réjouir de l'actualité du corpus lexical retenu, puisqu'il a été recueilli par les AA. dans les publications les plus diverses apparues au Turkménistan depuis la déclaration d'indépendance de cette ancienne république soviétique en 1991. De ce point de vue, le présent ouvrage présente un document original tout à fait passionnant sur l'état de la langue turkmène, telle qu'elle est pratiquée aujourd'hui dans la culture officielle au nord de l'Atrek. 
INDEX

Thèmes : 2.2. Langues vivantes et dialectes

\section{AUTEURS}

STÉPHANE A. DUDOIGNON

CNRS - Strasbourg 